\title{
Analysis of the Cost-Effectiveness of Antidiabetic Drugs among Self Paid Participant of the Indonesia National Security Service (NSS) with Type 2 Diabetes Mellitus
}

\author{
Firman Pribadi ${ }^{1 *}$, Iman Permana ${ }^{2}$
}

\begin{abstract}
Introduction: Medical care for patients with diabetes mellitus Type 2 is expensive, particularly in the presence of complications. Indeed, in the era of the National Health Security Program the effectiveness and efficiency of medical care provision has been regarded paramount. This study aimed to identify the difference of cost-effectiveness among the prescription of oral anti diabetic therapy, oral and oral, insulin, oral and insulin, and oral, oral, and insulin. Methods: This study was a retrospective study utilizing the out patients medical record of self paid participant of NSS in a hospital in Yogyakarta diagnosed with type 2 diabetes mellitus. Results: there are three types of anti diabetic drugs which have minus values in the ICER, namely Sulfonylureas, the combination of Biguanides, Sulfonylureas, and Thiazolindinedione, and the combination of Sulfonylureas and Biguanides. Conclusion: the combination of Sulfonylureas and Biguanides, which is a combination of oral and oral anti diabetic therapy, is the most costeffective medication with the ICER (Incremental Cost-Effectiveness Ratio) values of Rp $-170,208^{1}$

Keywords: Cost-Effective, ICER

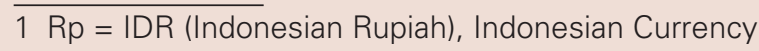

\section{Firman Pribadi ${ }^{*}$, Iman Permana ${ }^{2}$}

\author{
${ }^{\top}$ Master of Hospital Management - \\ Universitas Muhammadiyah Yogyakarta \\ Jalan Brawijaya, Taman Tirto Kasihan \\ Bantul - Yogyakarta,INDONESIA. \\ ${ }^{2}$ Faculty of Medicine and Health \\ Sciences - Universitas Muhammadiyah \\ Yogyakarta, INDONESIA. \\ Correspondence \\ Dr. Firman Pribadi, MSi \\ Lecturer of Master of Hospital \\ Management-Universitas Muham- \\ madiyah Yogyakarta, Jalan Brawijaya, \\ Taman Tirto Kasihan Bantul - Yogyakarta, \\ INDONESIA \\ Mobile no: +62-081329417382 \\ Email: firmanpribadi@umy.ac.id

\section{History} \\ - Submission Date: 22-04-2018 \\ - Revised Date: 13-06-2018 \\ - Accepted Date: 10-09-2018
}

DOI : 10.5530/ijmedph.2018.3.23

Article Available online

http://www.ijmedph.org/v8/i3

\section{Copyright}

(C) 2018 Phcog.Net. This is an openaccess article distributed under the terms of the Creative Commons Attribution 4.0 International license.

\section{INTRODUCTION}

Diabetes Mellitus (DM) is a metabolic disease characterized by hyperglycemia due to insulin secretion abnormalities, insulin work, or both. Complications, both microvascular and macrovascular diseases, will develop if adequate management has not been put into serious account. ${ }^{1,2}$

Medical care for patients with diabetes mellitus is considered to beexpensive, particularly in the presence of complications. According to the IDF report, the medication cost for DM ranges from USD 1500-9000 per patient per year in developed countries to USD 50-2000 in developing countries, and USD 80, 22 in Indonesia. Moreover, ASKES as the previous management body of health insurance in Indonesia reports in 2010, the management cost of DM was around USD 22.4 million with higher cost was produced from the complicated case (USD800) versus uncomplicated cases (USD40) for any patient a year. The less cost from Indonesia is believed to be correlated with the inadequate management of DM patients. ${ }^{2}$

Several studies in Yogyakarta show that the direct cost for DM patient range from USD 19.97 to USD 21 where the proportion for the medication cost is reaching $96,4 \%$ and $59.5 \%$ of the total cost. Furthermore, the combination of gliquidone-metforminacarbose with USD $39.44^{4}$ but also for the economic burden it places on the healthcare systems. The objectives of this study were to describe the healthcare cost for outpatient diabetes mellitus treatment and to examine the cost of different classes of anti-diabetic drugs. The medical records of Type 2 diabetes mellitus outpatients without compelling indication were retrospectively reviewed. Data was collected for patients treated from January $1^{\text {st }}$ to December $31^{\text {st }}$, 2004 in Kodya Yogyakarta Hospital. Data collected included patient demographics, drug acquisition cost, medical consultation cost and laboratory cost. We analysed charts of 100 consecutive patients, of whom $71 \%$ are women and $29 \%$ are men. The average age of patient was $61.2 \pm 13.7$ years. The monthly mean cost of Type 2 diabetes mellitus was found to be equivalent to USD19.97 \pm 13.71 . Most of the direct medical costs were spent on drugs $(96.4 \%$ and the combination of biguanid, a-glukosidase inhibitor and insulin with USD 57, as the most expensive regime of treatment. ${ }^{5}$

Indeed, in the era of National Security Service the effectiveness of the medical care and the efficiency are important. ${ }^{3}$ Furthermore, with the implementation of the Universal Coverage and INA CBGs or Indonesian Case Base Groups for hospital package payment system in 2019 , the hospital is responsible
Cite this article : Pribadi F, Permana I. Analysis of the Cost-Effectiveness of Antidiabetic Drugs among Self Paid Participant of the Indonesia National Security Service (NSS) With Type 2 Diabetes Mellitus. Int J Med Public Health. 2018;8(3):108-11. 
to cover any extra expense produce from any service outside the payment package received. Furthermore, the consideration of cost-effectiveness often happens in countries where drug reimbursement is strictly regulated for both public and private sectors. It then leads to the concept of pharmaco-economics.

The concept of pharmaco-economics came from the core of economic principle: how to provide high quality products at the lowest possible cost in the presence of scarce resources and those often diminishing. Several studies have been conducted to analyze the cost-effectiveness of therapy in hypertension management ${ }^{6}$ caused the drugtreatment cost represents a major issue in health economics. The aim of this study was to describe in patients characteristic when using antihypertensive drugs in polyclinic PMI hospital Bogor, determine in the most cost effective drugs for blood pressure reduced output and asses the influence of hypertensive in treatments to quality of life, analyzed the relationship between cost effectiveness and quality of life. In this research conducted a cross-sectional descriptive study. Analytical study was Cost Effectiveness inAnalysis (CEA). ${ }^{7}$ Other studies have been done in analyzing typhoid and post appendectomy treatment. ${ }^{8,9}$ A study was conducted to determine the difference between using insulin therapy and the combination of insulin and metformin therapy in terms of the cost-effectiveness and the effectiveness of the therapies among patients with type 2 diabetes mellitus. From the ACER (Average Cost-Effectiveness Ratio) values, it can be seen that the combination of insulin and metformin therapy was the most cost-effective..$^{10}$ Other study has also conducted to determine the cost-effectiveness of oral anti-diabetic medication among patients with type 2 diabetes mellitus. The study has found that from the ACER (Average Cost-Effectiveness Ratio) and ICER (Incremental Cost-Effectiveness Ratio) values, the lowest ones were the Biguanides group. Thus, oral anti-diabetic medication was cost-effective. ${ }^{11}$ Therefore, to gain more data on cost-effectiveness in type 2 diabetes therapy in Yogyakarta settings, it is regarded essential to conduct a study.

\section{MATERIALS AND METHODS}

This study was a non-experimental with a retrospective descriptive design, conducted using the hospital billing records and medical records to discover the cost effectiveness of anti-diabetic treatment. The location of study was a university hospital in Yogyakarta, Indonesia.

The population of the study was established from the outpatient medical record of self-paid participant of the National Security Service program and we use total sampling that all patient data that meet the criteria will be taken as a sample. Total number of samples collected were 102 samples for the period of research starting from January 1-December 31, 2015. The criteria inclusion for the sample was type $2 \mathrm{DM}$ patients with or without complication who were treated with oral and/ or insulin at least for one month, and NSS self-paid member. The study was excluding any sample without a complete medical records and/or cost billing, and any patient with TB, HIV and cancer. Of the 102 samples, only 56 people consisting of 26 males and 30 women were meeting the inclusion criteria.

Data analysis was conducted utilizing the medical records analysis to discover the treatment effectiveness according to several targets, such as: blood sugar level, direct medication cost which composed from cost of registration, consultation, oral anti-diabetic treatment, complications and laboratory.

The level of fasting blood glucose and 2 hours post prandial was established according to the Pharmacotherapy Handbook, Seven edition. ${ }^{12}$ The study was not utilizing the $\mathrm{HbA} 1 \mathrm{c}$ result due to the unavailability of the data. At time of the study, the measurement was not covered within the NSS program and only selected cases of DM patients were able to get measured based on individual opinion of the treating specialist.
Incremental Cost-Effectiveness Ratio (ICER) was utilized to analyze the cost effectiveness for each patient every month. ICER defined by the difference in cost between two medication regimes divided by the difference in their efficacy. To calculate the ICER, $\Delta \mathrm{C}$ was generated from the difference between the average of medication cost of $A$ and the average of medication of $\mathrm{B}$. While, $\Delta \mathrm{E}$ was from the difference of efficacy of medication $A$ and $B$. The ICER was considered as good if the rate was low. Thus, the more effective the medication, the less expensive the medication cost.

\section{RESULTS}

Table 1 below shows the grouping of patients by sex, age, diagnosis, and complications. The age row is used to identify the age range where the cases of type 2 diabetes mellitus occur, and the diagnose row will be used to see the number of complications that occur. As for the complications row, it shows the types of complications.

The cost-effectiveness analysis was determined by comparing the cost spent by an individual with the success of anti-diabetic drugs in reaching the desired target of blood sugar levels.

Table 2 above shows that drugs from the combination of Insulin and a-glucosidase inhibitor and the class of Thiazolidinediones are highly effective in lowering blood sugar levels with the effectiveness reaching $100 \%$. The second effective class is Sulfonylureas having the level of effectiveness of $66.7 \%$. The next with high effectiveness in the third place is the combination of Sulfonylureas and Biguanides. However, if the number of patients being successfully treated put into account, the type 2 diabetes mellitus patients are mostly treated using Biguanides, Sulfonylureas, and the combination of both drugs. Thus, it can be said that the use of these drugs is quite effective to lower blood sugar levels.

\begin{tabular}{|c|c|c|c|}
\hline & Description & Number & Percentage \\
\hline \multirow[t]{2}{*}{ Sex } & Male & 26 & $47 \%$ \\
\hline & Female & 30 & $53 \%$ \\
\hline \multirow[t]{4}{*}{ Age } & 15-24 Years Old & 1 & $2 \%$ \\
\hline & 25-44 Years Old & 6 & $11 \%$ \\
\hline & 45-64 Years Old & 41 & $73 \%$ \\
\hline & $65+$ Years Old & 8 & $14 \%$ \\
\hline \multirow[t]{3}{*}{ Diagnose } & $\begin{array}{l}\text { type } 2 \text { DM without any } \\
\text { complications }\end{array}$ & 26 & $46 \%$ \\
\hline & $\begin{array}{l}\text { type } 2 \text { DM with } 1 \\
\text { complication }\end{array}$ & 20 & $36 \%$ \\
\hline & $\begin{array}{l}\text { type } 2 \text { DM with more than } 1 \\
\text { complication }\end{array}$ & 10 & $18 \%$ \\
\hline \multirow[t]{11}{*}{ Complications } & Vertigo & 1 & $3 \%$ \\
\hline & Arthritis & 2 & $7 \%$ \\
\hline & Myalgia & 1 & $3 \%$ \\
\hline & Dyspepsia & 3 & $10 \%$ \\
\hline & Hypertension & 11 & $37 \%$ \\
\hline & Ischialgia & 1 & $3 \%$ \\
\hline & ISK & 1 & $3 \%$ \\
\hline & $\begin{array}{l}\text { Congestive Heart Failure } \\
\text { (CHF) }\end{array}$ & 4 & $13 \%$ \\
\hline & Dyslipidemia + Hypertension & 2 & $7 \%$ \\
\hline & Hypertension + CHF & 1 & $3 \%$ \\
\hline & Hypertension + Dyspepsia & 3 & $10 \%$ \\
\hline
\end{tabular}




\begin{tabular}{|c|c|c|c|}
\hline Antidiabetic Drugs & $\begin{array}{l}\text { Blood } \\
\text { Sugar } \\
\text { Levels } \\
\text { Reaching } \\
\text { the Target }\end{array}$ & $\begin{array}{c}\text { Total N } \\
\text { of Blood } \\
\text { Glucose } \\
\text { Test }\end{array}$ & $\begin{array}{c}\text { Effectiveness } \\
\text { (\%) }\end{array}$ \\
\hline Sulfonylureas & 2 & 3 & 66.7 \\
\hline Sulfonylureas + Biguanides & 5 & 12 & 62.5 \\
\hline $\begin{aligned} & \text { Sulfonylureas } \\
&+ \text { Thiazolidinediones }\end{aligned}$ & 1 & 2 & 50 \\
\hline $\begin{array}{l}\text { Sulfonylureas }+\alpha \text {-glucosidase } \\
\text { inhibitor }+ \text { Biguanides }\end{array}$ & 1 & 2 & 50 \\
\hline Biguanides & 2 & 4 & 50 \\
\hline $\begin{array}{c}\text { Biguanides }+ \text { Sulfonylureas }+ \\
\text { Thiazolidinediones }\end{array}$ & 3 & 5 & 60 \\
\hline Thiazolidinediones & 1 & 1 & 100 \\
\hline Insulin & 3 & 6 & 50 \\
\hline Insulin + Biguanides & 5 & 9 & 55.5 \\
\hline $\begin{array}{c}\text { Insulin }+ \text { Sulfonylureas }+ \\
\text { Biguanides }\end{array}$ & 0 & 2 & 0 \\
\hline Insulin $+\alpha$-glucosidase inhibitor & 2 & 2 & 100 \\
\hline
\end{tabular}

Blood glucose test in this study was a random blood glucose test because the hospital only did the blood glucose test at that moment.

Cost-effectiveness is an analysis on cost-effectiveness seen from the point of view of the hospital. The effectiveness is measured from patients' blood sugar compared to the desired target. The desired target of blood sugar levels are: fasting blood sugar of $\leq 126 \mathrm{mg} / \mathrm{dL}$, two-hour postprandial (GD2JPP) of $\leq 140 \mathrm{mg} / \mathrm{dL}$, or random blood sugar of $\leq 200 \mathrm{mg} / \mathrm{dL} .{ }^{12}$ The cost-effectiveness is measured using the ICER calculation as the criteria ${ }^{7}$.

From table 3 above, it can be seen that the $\Delta \mathrm{C}$ was the result of the difference between average medication $\mathrm{A}$ and $\mathrm{B}$, Where as $\Delta \mathrm{E}$ was from efficacy between madication A adn B. The ICER was generated by dividing $\Delta \mathrm{C}$ with $\Delta \mathrm{E}$. Indeed, the lesser the ICER of the medication regime. It is considered to be more effective and efficient. So there are three types of anti-diabetic drugs which have minus in the ICER values, namely Sulfonylureas having the ICER values of $\mathrm{Rp}-4,857$, the combination of Biguanides, Sulfonylureas, and Thiazolindinedione having the ICER values of Rp-69,368 and the combination of Sulfonylureas and Biguanides having the ICER values of Rp -170,208. The negative values refer to the most effective rate. From this table, then, it can be concluded that the most cost-effective anti-diabetic drugs are the combination of Sulphonylureas and Biguanides with the ICER values of Rp -170,208.

\begin{tabular}{|c|c|c|c|c|c|}
\hline Anti-diabetic Drugs & Average Cost (\%) & $\begin{array}{c}\text { Effectiveness } \\
\text { (\%) }\end{array}$ & $\Delta C$ & DE & ICER \\
\hline Sulfonylurea + Biguanides & 47,400 & 62.5 & $(425,520)$ & 2.5 & $-170,208$ \\
\hline Sulfonylureas + Thiazolidinediones & 385,800 & 50 & $(919,550)$ & 0 & 0 \\
\hline Biguanides + Sulfonylureas + Thiazolidinediones & 472,920 & 60 & $(312,158)$ & 4.5 & $-69,368$ \\
\hline Thiazolidinediones & 227,200 & 50 & $(10,900)$ & 0 & 0 \\
\hline Insulin & $1,305,350$ & 50 & 392,800 & 50 & 7,856 \\
\hline Insulin + Biguanides & 785,078 & 55.5 & 770,778 & 5.5 & 140,141 \\
\hline
\end{tabular}

\section{CONCLUSION}

The combination of Sulfonylureas and Bigunaides is the most frequently used drugs in anti-diabetic medication and the most cost-effective therapy with the lowest ICER values of - (minus) Rp 170,208. Despite the significance results, the study also found that the absence of factors as diet and physical activity could serve as the limitation from this study. Those factors are considered essential in maintaining blood glucose level. This limitation was occurred due to the unavailability of data from the hospital. Further study should consider collaborating those data, as well as other factors related to the blood glucose level, to generate a more realistic and accurate results.

\section{CONFLICT OF INTEREST}

The authors declare no conflict of interest.

\section{ACKNOWLEDGEMENT}

We would like to convey our gratitude to the School of Master of Hospital Management, Universitas Muhammadiyah Yogyakarta for the research grant.

\section{REFERENCES}

1. American Diabetes Association (ADA) Standards of Medical Care in Diabetes -2010. Diabetes Care - Supplemen 1 2010; Vol 33.

2. Soewondo P. Harapan Baru Penyandang Diabetes Mellitus pada Era Jaminan Kesehatan Nasional 2014. EJournal Kedokteran Indonesia 2014.

3. Soewondo P, Ferrario A, Tahapary DL. Challenges in diabetes management in Indonesia: a literature review. Globalization and Health 2013;9(1):63.

4. Andayani TM, Imaningsih I. Cost Analysis of Anti-diabetic Drugs for Diabetes Mellitus Outpatient in Kodya Yogyakarta Hospital. n.d.:5.

5. alnnidonesia Mt. Analisis biaya terapi Diabetes mellitus di Rumah Sakit Dr. Sardjito Yogyakarta 2006:6.

6. Erni R, Retnosari A, Liana A. Analisis Penggunaan Obat Antihipertensi di Poliklinik 
Rawat Jalan Rumah Sakit PMI Bogor: Perbandingan Cost Effectivenessdan Kualitas Hidup Pasien. Jurnal ILMU Kefarmasian Indonesia. 2014;12(2):209-15.

7. Alisa P, Nurul Mutmainah Analisis Eefektivitas Biaya Antidiabetik Oral Pada Penderita Diabetes Melitus Tipe 2 Rawat Jalan Peserta BPJS Di Rumah Sakit Umum Daerah DR. Moewardi Tahun 2014. Naskah Publikasi Fakultas Farmasi Universitas Muhammadiyah Surakarta n.d.

8. Lili M, Afdhal AF, Ascobat G, et al. Analisis Efektivitas Biaya Pengobatan Demam Tifoid Anak Menggunakan Kloramfenikol Dan Seftriakson Di Rumah Sakit Fatmawati Jakarta Tahun 2001 - 2002. Makara, Kesehatan 2004;8(2):59-64.

9. Muhartati SA, Muhlis M, Supadmi W. Analisis cost-Effectiveness penggunaan Seftriakson Dan Sefotaksim Pada Terapi Profilaksis Apendektomi Di Rs Pku Muhammadiyah Yogyakarta Tahun 2006- 2007. Jurnal IImiah Kefarmasian. 2011:1(2):79-89.
10. Wijayanti NW, Mukaddas A, Tandah MR. Analisis Efektifitas Biaya Pengobatan Kombinasi Amlodipin Furosemid Dibandingkan dengan Kombinasi Amlodipin Bisoprolol pada Pasien Hipertensi Rawat Jalan di Rsud Undata Palu Periode Agustus-Oktober T ahun 2014. Online Jurnal of Natural Science. 2016;5(1):10110.

11. Esti Pramestiningtyas, Prihwanto Budi S, Wiratmo, et al. Analisis Efektivitas Biaya Berdasarkan Nilai ACER Penggunaan Insulin Dibandingkan Kombinasi Insulin-Metformin pada Pasien Diabetes Melitus Tipe 2 di Instalasi Rawat Inap RSD dr.Soebandi Jember Periode 2012 (Cost Effectiveness Analysis Based on ACER Value of Insulin Compared to Insulin-Metformin Combination in Type 2 Diabetes Mellitus Patients in Inpatient RSD dr. Jember Soebandi Period 2012 ). Artikel IImiah Hasil Penelitian Mahasiswa 2012.

12. Wells BG, DiPiro JT, Matzke GR, et al. Pharmacotherapy Handbook (7th Edition). New York, USA: McGraw-Hill Professional Publishing. 2009.

Cite this article : Pribadi F, Permana I. Analysis of the Cost-Effectiveness of Antidiabetic Drugs among Self Paid Participant of the Indonesia National Security Service (NSS) With Type 2 Diabetes Mellitus. Int J Med Public Health. 2018;8(3):108-11. 